\title{
GROWTH PERFORMANCE, CARCASS TRAITS AND ECONOMIC EFFICIENCY OF BARKI LAMBS FED AZZAWI DATE
}

\author{
I. Mona Mohammady*, I. M. Khattab, M.F. Shehata, A.M. Abdel-Wahed and K.Z. Kewan \\ Division of Animal Production and Poultry, Desert Research Center, 1 Matahaf El Mataria St., P.O. Box \\ 11753, Mataria, Cairo, Egypt, *Corresponding author :(monamohammady@hotmail.com)
}

\section{SUMMARY}

Twenty one Barki lambs (aging 5 months with $24.2 \pm 3 \mathrm{~kg}$ average body weight) were randomly divided into three equal groups to assess the effect of replacing corn grains by Azzawi date in lamb's diet on growth performance, carcass traits and economic efficiency. Experimental diets were of three levels, $0 \%$ date (control), $50 \%$ date (D50) and $100 \%$ date (D100). Results indicated that, inclusion of Azzawi date did not affect significantly dry matter intake, digestibility \%, nutritive values (DCP\% and TDN \%) and nitrogen balance. Results of growth, feed conversion and most of carcass traits showed that no significant differences were detected among the studied groups. Economical indicators revealed that replacing corn grains with Azzawi date led to $22.7 \%$ reduction in feeding cost per one $\mathrm{kg}$ of live body weight. The D100 group achieved the highest gross margin (LE436.5), whereas, the control group was the lowest (LE323.4). Break - even yield of D100 group was lower than control one $(40.2 \mathrm{~kg} v \mathrm{~s} .42 .6 \mathrm{~kg})$ to generate profit. In addition to, break - even price of D100 group was cheaper than control group (LE 27.4 vs. LE 29.5), respectively .

Keywords: Azzawi date, performance, carcass traits, economic efficiency, Barki lambs

\section{INTRODUCTION}

Many producers believe that the only way to enhance profit is to increase income, however, this goal be achieved by lowering expenses or increasing productivity. However, production cost is probably a more realistic way to increase the net income from sheep enterprise. Under Egyptian conditions, red meat production depends mainly on fattening of growing animals up to the marketing body weight (El-Asheeri, 2008). Cost of feeding represents the major component of the livestock operation costs. Grains are considered as one of the most common feeds used for growing and finishing lambs. However, based on availability and market price, grains frequently account for $60-70 \%$ of concentrate feed mixture costs (Harb, 1994). Throughout the last years, red meat production in Egypt faced many constrains that led to increase meat market price. Finding non-conventional feeds that can replace part of the grains may economically be advantageous to reduce the feeding costs, consequently improve the profitability of sheep enterprise (Al Jassim et al., 1998 and Belal et al., 2008). The availability, good nutrients content and low price of Azzawi date in the semi-arid areas in Egypt may give the opportunity to lower the feeding costs. Few studies are available to identify and measure the economical efficiency of utilizing Azzawi date in sheep enterprises under semi-arid conditions in Egypt. The present study was designed to investigate the effect of replacing corn grains by Azzawi date, as a source of non-conventional energy, on growth performance, feed conversion ratio, carcass characteristics and economical efficiency of fattening Barki lambs.

\section{MATERIALS AND METHODS}

The current experiment was conducted at Maryuot Research Station, Desert Research Center, Ministry of Agriculture and Land Reclamation which located at $35 \mathrm{~km}$ south of Alexandria, Egypt. The experimental period lasted for 173 days.

\section{Experimental Animals}

Twenty-one Barki lambs aging 5 months with an average live body weight of $24.2 \pm 3.0 \mathrm{~kg}$ ) were randomly divided into three equal groups. Animals were housed in shaded pens and fed twice a day (at 09:00 and 15:00 h) and had free access to water and vitamin/mineral block.

\section{Experimental feeding diets}

The current study used three levels of Azzawi date to replace corn grains in concentrate feed mixture. Chemical composition and fiber fractionations (\%) of Azzawi date and corn grains are presented in (Table 1).

The first group of lambs was fed traditional concentrate feed mixture (CFM) free of Azzawi date (control). This concentrate mixture consisted of $50 \%$ undecorticated cotton seed $18 \%$ cake, wheat bran, $15 \%$ yellow maize, $11 \%$ rice $3 \%$ polish, molasses, $2 \%$ limestone and $1 \%$ common salt. The second group of lambs was fed CFM with $50 \%$ replacement of corn grains with Azzawi date (D50). The third group of lambs was fed CFM with $100 \%$ replacement of corn grains by Azzawi date (D100). Diets composed of 50\% roughage (Alfalfa hay) and $50 \%$ concentrate mixture (as fed). Animals were fed according to NRC requirements (1985). The dietary ingredients of the formulated 
CFM are presented in (Table 2). Lambs were given a 2-week adaptation period before receiving the experimental diets.

\section{Digestion and $N$ balance experiment}

At the end of the fattening period, three animals from each group were selected randomly and housed individually in metabolism crates that allowed separation of urine and faces to evaluate nutrient digestibility and $\mathrm{N}$ balance. Animals were given 7 days as an adaptation period for the metabolism crates followed by a 6-day collection period. During the 6-day collection period, feed intake and refusals were recorded. Feed samples and refusals were sampled for further analysis. Daily fecal output was collected, weighed, and recorded, and then $10 \%$ of it was kept for subsequent analyses. Using plastic containers, urine was collected, weighed, and recorded, and then $10 \%$ of it was kept to evaluate $\mathrm{N}$ retention. Each bottle had $100 \mathrm{~mL}$ of $\mathrm{H} 2 \mathrm{SO} 4(10 \%)$ to prevent $\mathrm{N}$ losses. Samples of feeds and refusals were dried at $\left(60{ }^{\circ} \mathrm{C}, 48 \mathrm{~h}\right)$, while fecal samples were dried at $(80$ ${ }^{\circ} \mathrm{C}, 48 \mathrm{~h}$ ) to determine dry matter (DM) content in a forced-air oven to reach a constant weight, air equilibrated, and then ground to pass $1 \mathrm{~mm}$ screen for further analysis. During the digestibility and $\mathrm{N}$ balance experiment, feed, refusals, and feces were analyzed for proximate chemical analysis

\section{Data}

All Lambs in each treatment were weighed at the beginning (initial body weight) of the study and biweekly, thereafter, before the morning feeding throughout the study. Average dry matter intake of each group was calculated during the experimental period. The experiment period lasted for 173 days. At the end of the experiment, all lambs of each group (7 lambs/group) were slaughtered after $24 \mathrm{~h}$ fasting period to evaluate carcass traits. Animals were skinned; abdominal and thoracic organs were detached and weighed. The digestive tract was weighed both full and empty to get the gut fill weight by subtraction. the empty body weight (EBW) was obtained by subtracting alimentary tract content from pre-slaughter weight. Hot carcass weight was determined immediately after evisceration and expressed as percentage of slaughter weight and empty body weight to estimate dressing percentage (Koch et al., 1963). Some studied data traits expressed as a percentages, especially if less than $30 \%$ or higher than $70 \%$, were analyzed after transforming percentages by arcsine transform method.

Table 1.Chemical composition and fiber fractionations (\%) of Azzawi date and Corn grain

\begin{tabular}{lcc}
\hline Item & Corn grains & Azzawi date \\
\hline Crude protein & 8.5 & 7.4 \\
Crude fiber & 2.54 & 7.52 \\
Ether extract & 4.16 & 3.83 \\
Nitrogen free extract & 83.19 & 76.92 \\
Ash & 1.58 & 4.31 \\
Netural detergen fiber & 21.41 & 18.83 \\
Acid detergent fiber & 5.36 & 18.28 \\
Sugar & 8.28 & 46.95 \\
\hline
\end{tabular}

Khattab et al., 2012

Table 2. Dietary ingredients used in formulating the CFM as fresh basis

\begin{tabular}{|c|c|c|c|}
\hline \multirow[b]{2}{*}{ Ingredients } & \multicolumn{3}{|c|}{ Diets $^{1}$} \\
\hline & G1 & G2 & G3 \\
\hline Azzawi date & 0 & 27.5 & 55 \\
\hline Corn grain & 55 & 27.5 & 0 \\
\hline Soybean meal & 16 & 18 & 19 \\
\hline Cotton seed meal & 10 & 10 & 10 \\
\hline Wheat bran & 17 & 15 & 14 \\
\hline Salt, NaCl & 0.7 & 0.7 & 0.7 \\
\hline Limestone & 1 & 1 & 1 \\
\hline Vitamin mineral premix ${ }^{2}$ & 0.3 & 0.3 & 0.3 \\
\hline
\end{tabular}

1, Diets were: G1, free Azzawi date (Control), G2, 50\% Azzawi date (D50), and G3, 100\% Azzawi date (D100) substitute for corn grain. Composition per $3 \mathrm{~kg}$ contained: Vit. A; 10,000,000 IU, Vit. D3; 2,000,000 IU, Vit. E; 10,000 mg, Vit K3; 1000 mg, Vit. B1; 1,000 mg, Vit. B2; 5,000 mg, Vit. B6; 1500 mg, Vit. B12; 10 mg, Biotin; 50 mg, Nicotinic; 30,000 mg, Pantothenic; 10,000 mg, Mn; 60,000 mg, Zn; 50,000 mg, Se; $100 \mathrm{mg}$, Co; $100 \mathrm{mg}$, Fe; 30,000 mg, Cu; 4,000 mg, Iodine; $300 \mathrm{mg}$. 
Table 3. Chemical composition of concentrate fed mixture (CFM) and berseem hay (on DM basis) of the experimental diets

\begin{tabular}{lcccc}
\hline & \multicolumn{3}{c}{ Diets $^{\mathbf{1}}$} & \multirow{2}{*}{ Alfalfa hay } \\
\cline { 2 - 4 } Chemical Composition & G1 & G2 & G3 & \\
\hline Dry matter & 89.49 & 88.52 & 89.53 & 88.39 \\
Organic matter & 94.44 & 90.69 & 89.94 & 90.78 \\
Crude protein & 16.66 & 16.94 & 16.89 & 16.05 \\
Ether extract & 3.77 & 3.64 & 3.54 & 2.28 \\
Crude fiber & 6.71 & 8.01 & 9.35 & 27.35 \\
Nitrogen free extract & 67.3 & 62.1 & 60.16 & 45.1 \\
Ash & 5.56 & 9.31 & 10.06 & 9.22 \\
\hline
\end{tabular}

1, Diets were: G1, free Azzawi date (Control), G2, 50\% Azzawi date (D50), and G3, 100\% Azzawi date (D100).

\section{Diets analysis}

The studied feeding diets were formulated and analyzed in duplicate for proximate chemical analysis according to AOAC (2000). The results of chemical composition are shown in (Table 3).

\section{Statistical analysis}

Data were statistically analyzed by one- way analysis of variance using the General Linear Model (GLM) procedures described by SAS (2004), and applying the following model :

Where:

$$
\mathbf{Y}_{\mathrm{ij}}=\mu+\mathbf{d}_{\mathrm{i}}+\mathbf{e}_{\mathrm{ij}}
$$

$\mathrm{Y}_{\mathrm{ij}}=$ the observations,

$\mu=$ the overall mean ,

$\mathrm{d}_{\mathrm{j}}=$ the effect due to $\mathrm{i}^{\text {th }}$ type of feeding, $\mathrm{i}=1,2,3$,

$\mathrm{e}_{\mathrm{ij}}=$ random error associated with the $\mathrm{ij}^{\text {th }}$ observation. Differences among treatments were tested according to Duncan's new multiple ranges Test (Duncan, 1955).

\section{Economic Analysis}

Financial analysis is needed in order to measure the profitability of fattening lambs under such diets. The financial data included, variable costs of the following inputs; feed (concentrate feed mixture, roughage), and non-feed inputs (veterinary costs, labor wages), while, total revenues represent the sales of live fattened lambs, and manure. Economical indicators of the current study was conducted by two methods, the first consider the feeding costs only to evaluate the impact of replacing corn grains on feeding costs per one kilogram gain for both live body weight and carcass weight of the three studied groups. The second method takes into account all the operating costs to estimate the economical efficiency under such feeding diets. Gross margin per lamb, benefit/cost ratio $(\mathrm{B} / \mathrm{C})$ and break - even point were used as financial criteria to compare the economical efficiency of fattened lambs among the studied groups and was calculated as follow .

Revenues $=$ final body weight* number of animals* price of $\mathrm{kg}$,

Total gross margin $=$ total revenue - variable costs, economical efficiency (gross margin per lamb) = total gross margin / no. of lambs,

$\mathrm{B} / \mathrm{C}=$ total revenues / total costs ,Break - even price $=$ total costs $/$ expected yield,
Break - even yield $=$ total costs $/$ expected price .

\section{RESULTS AND DISCUSSION}

\section{Dry matter intake, Digestibility \% and nitrogen balance}

Results of the digestibility experiment are shown in (Table 4). No significant differences were detedted among diets for Dry matter intake (DMI, $\mathrm{kg} / \mathrm{d})$. This result is due to that the ME of corn grains and dates are comparable, 10.5 and 9.9 $\mathrm{MJ} / \mathrm{kg}$ DM (Khattab et al., 2012). The current results showed that, crude protein digestibility decreased $(\mathrm{P}<0.05)$ with inclusion of date, while, digestibility of dry matter, organic matter, ether extract, crude fiber and nitrogen free extract were not affected with date inclusion level. Also, the digestible crude protein (DCP) $\%$ and total digestible nutrients (TDN) \% were not affected with Azzawi date level. The values were comparable, and this means that lambs were received comparable values from protein and energy.

Results of nitrogen balance are shown in (Table 4). All lambs were in a positive nitrogen balance. No significant differences were observed in nitrogen balance among the experimental diets. Al-Dabeeb (2005) found that digestibility of DM, $\mathrm{OM}, \mathrm{CP}, \mathrm{NFE}, \mathrm{CF}$ and nitrogen balance decreased with increasing level of dates in the diet. El-Hag et al. (1993) reported a similar drop in digestion coefficients of $\mathrm{CP}$ and $\mathrm{CF}$ due to the inclusion of dates in the ration of sheep. Hmeidan et al., (1993) reported that using dates as an energy source up to the level of $44 \%$ resulted in a significant decrease in nutrient digestibility, $\mathrm{N}$ retention and energy utilization.

\section{Biological performance \\ Live weight gain}

Least squares means and standard errors (LSM $\pm \mathrm{SE}$ ) of the studied traits are shown in (Table 5). Analysis of variance showed that, no significant differences were observed among the obtained means of the studied traits. The result illustrated that, the average daily gain (ADG) of the control group and (D100) are almost similar, 154g and $155 \mathrm{~g}$, respectively, which means that total replacement of corn grains, in concentrate feed 
mixture, by Azzawi date have not any negative effects on ADG .

These results are in agreement with Al-Dabeeb (2005) who found that, incorporation of dates at $10 \%$ or $20 \%$ of the diet did not show any improvement in growth rate when compared with the control group. These findings are contrary to that of El-Gasim (1986) and El-Hag et al. (1993) who reported that the addition of discarded dates at the levels of $15 \%$ or $25 \%$ of the whole DM of ration was associated with an increase in the growth rate of Awassi lambs.

Table 4. Least squares means and standard errors of (LSM \pm SE) body weight, Dry matter intake (DMI), digestibility of nutrients and Nitrogen balance in the experimental diets with increasing amounts of date replacing corn grain fed to Barki lambs

\begin{tabular}{|c|c|c|c|}
\hline \multirow[b]{2}{*}{ Item } & \multicolumn{3}{|c|}{ Diets $^{1}$} \\
\hline & G1 & G2 & G3 \\
\hline No. of Lambs & 3 & 3 & 3 \\
\hline $\mathbf{B W}, \mathbf{k g}$ & $49.33 \pm 0.60$ & $49.50 \pm 2.08$ & $50.50 \pm 1.32$ \\
\hline Dry matter intake, kg/d & $1.34 \pm 0.10$ & $1.47 \pm 0.07$ & $1.45 \pm 0.07$ \\
\hline \multicolumn{4}{|l|}{ Digestibility, \% } \\
\hline Dry matter & $72.45 \pm 0.72$ & $71.08 \pm 0.29$ & $69.73 \pm 1.25$ \\
\hline Organic matter & $72.33 \pm 0.96$ & $72.97 \pm 1.36$ & $73.36 \pm 1.75$ \\
\hline Crude protein & $77.38 \pm 1.17^{\mathrm{a}}$ & $72.97 \pm 1.04^{\mathrm{b}}$ & $71.49 \pm 1.21^{\mathrm{b}}$ \\
\hline Ether extract & $68.56 \pm 1.49$ & $68.09 \pm 2.33$ & $67.04 \pm 1.84$ \\
\hline Crude fiber & $65.15 \pm 1.13$ & $63.52 \pm 0.44$ & $62.84 \pm 2.61$ \\
\hline Nitrogen free extract & $74.72 \pm 1.29$ & $76.24 \pm 2.80$ & $76.67 \pm 1.73$ \\
\hline \multicolumn{4}{|l|}{ Nutritive value, $\%$} \\
\hline Digestible crude protein & $12.68 \pm 0.11$ & $12.06 \pm 0.36$ & $11.79 \pm 0.71$ \\
\hline Total digestible nutrients & $69.23 \pm 1.08$ & $68.25 \pm 1.27$ & $68.47 \pm 1.26$ \\
\hline \multicolumn{4}{|l|}{ Nitrogen balance } \\
\hline $\mathbf{N}$ intake, $g / d$ & $35.20 \pm 0.97$ & $38.84 \pm 1.57$ & $38.36 \pm 1.49$ \\
\hline Fecal N, g/d & $14.46 \pm 0.14$ & $16.92 \pm 1.07$ & $17.99 \pm 1.48$ \\
\hline Urinary $N, g / d$ & $11.05 \pm 0.62$ & $12.94 \pm 0.66$ & $11.60 \pm 0.40$ \\
\hline \multicolumn{4}{|l|}{$\mathrm{N}$ retention } \\
\hline g/d & $9.69 \pm 0.90$ & $8.98 \pm 1.12$ & $8.77 \pm 0.62$ \\
\hline$\%$ of $\mathrm{N}$ intake & $27.47 \pm 2.11$ & $23.09 \pm 2.59$ & $22.86 \pm 1.26$ \\
\hline$\%$ of $\mathrm{N}$ absorbed & $46.59 \pm 2.84$ & $40.70 \pm 2.93$ & $42.99 \pm 2.11$ \\
\hline
\end{tabular}

1, Diets were: G1, free of Azzawi date (Control), G2, 50\% Azzawi date (D50), and G3, 100\% Azzawi date (D100). Values having different letters $(a, b)$ within row are different $(\mathrm{P}<0.05)$.

Table 5. Growth performance and feed conversion ratio of Barki lambs fed different levels of Azzawi date

\begin{tabular}{lccc}
\hline \multirow{2}{*}{ Item } & \multicolumn{3}{c}{ Diets $^{\mathbf{1}}$} \\
\cline { 2 - 4 } & G1 & G2 & G3 \\
\hline No. of animals & 7 & 7 & 173 \\
Exp. period (days) & 173 & 173 & \\
Body weight changes: & & & $24.5 \pm 1.43$ \\
Initial body wt (kg) & $23.85 \pm 1.43$ & $24.21 \pm 1.43$ & $51.36 \pm 3.09$ \\
Final body wt (kg) & $50.50 \pm 3.09$ & $50.78 \pm 3.09$ & $26.9 \pm 2.041$ \\
Total gain (kg/ head) & $26.6 \pm 2.041$ & $26.6 \pm 2.041$ & $155 \pm 012$ \\
Average Daily gain (g/head/day) & $154 \pm .012$ & $150 \pm 012$ & 658.04 \\
Daily feed intake (g DM/head) & & & 649.67 \\
Concentrate mixture & 657.75 & 650.62 & 1307.71 \\
Roughages & 649.67 & 649.67 & 226.23 \\
Total DM intake / head/day & 1307.42 & 1300.29 & 1583.64 \\
Total DM intake/h/period & 226.18 & 224.95 & 8.41 \\
Total feed intake & 1583.285 & 1574.65 & 8.47 \\
FCR (kg DM/kg gain) & 8.49 & & \\
\hline
\end{tabular}

1, Diets were: G1, free of Azzawi date (Control), G2, 50\% Azzawi date (D50), and G3, 100\% Azzawi date (D100).

FCR, feed conversion ratio

Feed conversion ratio:

Results of Feed conversation ratios of the three studied groups are shown in (Table 5). Results showed that, feed conversation ratio (FCR) did not differ among the treatment groups but, there was a slight decrease in quantity of dry matter needed to 
produce one $\mathrm{kg}$ gain (FCR) in favor of D 100, which was slightly more efficient than the other two groups (8.41 vs. 849 and 8.47), respectively. This might be due to the absence of significant differences among the initial body weights. Also, amount of DM consumed seemed to be similar per head entered the feedlot. In addition to corn grains and dates have similar energy content (Khattab et al., 2012). This result is in agreement with, ElGasim (1986), El-Hag et al. (1993) and Almitairy et al. (2011).

\section{Carcass and non-carcass characteristics}

Least squares means of percentages of offals (heart, liver, lungs \& trachea, spleen, kidneys and testes) and non-carcass components (head, feet, and pelt) are presented in (Table 6). Results showed that, there are no significant differences among the groups in most organs and offals percentages, but differences were significant for the pelt, abdominal fat and testes fat percentages. These results are in agreement with Almintairy et al. (2011) who said that, no significant differences were found between treatment and control diet in weight of organs and offals of Najdi lambs. In this context, (Table 6) revealed that, no significant differences were observed among groups in slaughter weight, empty body weights, hot carcass weight and dressing percentages, but there was, there is a slightly increase in control group in dressing percentage than the other two groups. These results may be due to that, the percentage of total offals was higher in D 50 and D 100 than the control one. This result is agree with, Safari et al. (2011), who said that, the non-carcass parts form $30-35 \%$ of the total live body weight in sheep and have much influence on dressing percentage. Consequently, the increase or decrease of non-carcass parts is inversely proportional to the yield of carcass part (Suliman and Babiker, 2007 and Sen et al., 2011).

Table 6. Least squares means ${ }^{1}$ and standard errors (LSM \pm SE) of slaughter wt (kg), empty body wt (kg), hot carcass wt $(\mathrm{kg})$, dressing percentage and organs and offals (\%) of Barki lambs fed different levels of Azzawi date

\begin{tabular}{|c|c|c|c|c|}
\hline \multirow[b]{2}{*}{ Item } & \multicolumn{3}{|c|}{ Diets $^{2}$} & \multirow[b]{2}{*}{$\pm \mathrm{SE}$} \\
\hline & G1 & G2 & G3 & \\
\hline Slaughter wt (kg) & $50.50^{\mathrm{a}}$ & $50.79^{\mathrm{a}}$ & $51.37^{\mathrm{a}}$ & 2.84 \\
\hline Empty Body wt (kg) & $43.73^{\mathrm{a}}$ & $44.97^{\mathrm{a}}$ & $44.36^{\mathrm{a}}$ & 2.58 \\
\hline Hot carcass wt $(\mathrm{Kg})$ & $24.33^{\mathrm{a}}$ & $23.78^{\mathrm{a}}$ & $24.35^{\mathrm{a}}$ & 1.38 \\
\hline \multicolumn{5}{|l|}{ Dressing \% } \\
\hline$\%$ of slaughter wt & $48.02^{\mathrm{a}}$ & $47.07^{\mathrm{a}}$ & $47.36^{\mathrm{a}}$ & 0.82 \\
\hline \% of empty body wt & $55.49^{\mathrm{a}}$ & $53.09^{\mathrm{a}}$ & $54.98^{\mathrm{a}}$ & 0.84 \\
\hline \multicolumn{5}{|l|}{ Organs and offals $\%^{1}$} \\
\hline$\overline{\text { Head }}$ & 7.81 & 8.34 & 7.46 & 0.23 \\
\hline Feet & 2.14 & 2.13 & 2.11 & 0.16 \\
\hline Pelt & $12.20^{\mathrm{b}}$ & $15.04^{\mathrm{a}}$ & $15.29^{\mathrm{a}}$ & 0.31 \\
\hline Lungs \& Trachea & 1.35 & 1.45 & 1.56 & 0.17 \\
\hline Heart & 0.43 & 0.39 & 0.38 & 0.14 \\
\hline Liver & 1.39 & 1.45 & 1.39 & 0.16 \\
\hline Spleen & 0.13 & 0.13 & 0.13 & 0.11 \\
\hline Kidneys & 0.30 & 0.27 & 0.30 & 0.13 \\
\hline Testes & 0.80 & 0.85 & 0.88 & 0.16 \\
\hline Abdominal fat & $1.77^{\mathrm{a}}$ & $1.27^{\mathrm{b}}$ & $1.46^{\mathrm{b}}$ & 0.22 \\
\hline Kidney fat & 1.13 & 0.80 & 0.99 & 0.23 \\
\hline Testes fat & $0.85^{\mathrm{a}}$ & $0.57^{\mathrm{b}}$ & $0.57^{\mathrm{b}}$ & 0.19 \\
\hline Non- edible parts ${ }^{2}$ & $22.15^{\mathrm{b}}$ & $25.51^{\mathrm{a}}$ & $25.16^{\mathrm{a}}$ & 0.27 \\
\hline Edible parts ${ }^{3}$ & $2.12^{\mathrm{a}}$ & $2.12^{\mathrm{a}}$ & $2.07^{\mathrm{b}}$ & 0.18 \\
\hline
\end{tabular}

1 , Means followed by different superscripts differ significantly $(\mathrm{p}<0.05)$.

2, Diets were: G1, free of Azzawi date (Control), G2, 50\% Azzawi date (D50), and G3, 100\% Azzawi date (D100).

1 , expressed as a percentage of empty body wt, 2, Non- edible parts (Head + feet + pelt), 3, Edible parts $($ Heart + liver + kidneys

\section{Economic indicators}

Economical indicators of the current study are presented in Table (7). From an economical point of view, comparing total feeding cost, results showed that, there is a positive trend in CFM as the level of Azzawi date increased. In this context, results of feeding cost per one $\mathrm{kg}$ gain revealed considerable decrease in feeding cost, whereas, cost of control group required a higher cost, while the third group (D 100) was the lowest one (LE 18,14 vs. LE 14,01) which represent about $22.7 \%$ decline of this expense. Similar trend was observed in case of carcass, where, feeding cost in one kg of carcass gain was estimated as LE 29.9 of the third group (D 100), which represented about $20.85 \%$ lower in feeding cost than the control one. Benefit/cost ratio declared that, lambs fed $100 \%$ date earned the highest value of LE 2.34, while, the control group was the lowest (LE 1.85). 
Results of gross margin are presented in (Table 8). Using Azzawi date with different levels influenced the economical efficiency of the three studied groups. The third group (D100) achieved the highest gross margin per head, estimated as LE 436.49 , while the control group was the lowest and achieved 323.4 L.E. This might be due to that replacement of corn grains had a significant impact on feeding costs and consequently, reduced the total variable costs. Similar results were observed by Al Dabeeb et al. (2009) who reported that, Date supplementation in diets reduced the feeding costs during the whole fattening period of Najdi lambs by about $\$ 1.85$ and 3.91 in D10 and D20, respectively. The author added that, diet supplemented with $20 \%$ dates was higher in economic efficiency by about $4.2 \%$ relative to the control diet. Nevertheless, the diet supplemented with $10 \%$ dates was lower in economic efficiency by about $9.0 \%$ relative to the control diet. Break-even points obtained from the recent study showed that reducing feeding costs had positive benefits for both the producer and the consumer (Table 8). Concerning producer side, break-even yield revealed that producer of D 100 need to reach lower live body weight than control one to generate profits $(40.2 \mathrm{~kg} v s .42 .6 \mathrm{~kg}$ ), respectively. In the meantime, consumer can get cheaper price for one $\mathrm{kg}$ of live body weight produced from D 100 than that from the control group (LE 27.4 vs. LE 29.5, respectively).

Table 7. Economical indicators of incorporating different levels of Azzawi date in diets of Barki lamb

\begin{tabular}{lccc}
\hline Item & $(\mathbf{G 1})$ & $(\mathbf{G} 2)$ & (G3) \\
\hline No. of animals & 7 & 7 & 7 \\
Feeding cost per group: & & & 1378.6 \\
Concentrate feed mixture( LE) & 2118.78 & 1638.8 & 1258.80 \\
Roughages & 1258.80 & 1258.80 & 2637.4 \\
Total feed cost: & 3377.58 & 2897.6 & 14.01 \\
Feeding cost per kg gain & 18.14 & 15.56 & $-22.76 \%$ \\
Feeding cost comparison: & --- & $-14.2 \%$ & 2.50 \\
Benefit/Cost ration & 1.92 & 2.25 & 29.9 \\
Feeding cost/ kg carcass gain & 37.78 & 33.11 & -20.85 \\
Feeding cost comparison & & $-12.36 \%$ & 2.34 \\
Benefit/Cost ratio (carcass) & 1.85 & 2.11 & \\
\hline
\end{tabular}

1, Diets were: G1, free of Azzawi date (Control), G2, 50\% Azzawi date (D50), and G3, 100\% Azzawi date (D100).

Budget assumptions: Prevailing market prices were applied to conduct budget analysis.

Table 8. Gross margin (LE) of Barki lambs fed different levels of Azzawi date

\begin{tabular}{lccc}
\hline \multirow{2}{*}{ Item } & \multicolumn{2}{c}{ Diets $^{1}$} & (G3) \\
\cline { 2 - 4 } Revenues: & (G1) & 7 \\
No. of animals & 7 & 7 & 12583.2 \\
Lambs sold value & 12372.5 & 12441.1 & 331.78 \\
Manure & 331.78 & 331.78 & 12914.98 \\
Total revenues & 12704.28 & 12772.88 & \\
Variable cost: & & & 602.5 \\
Purchased lambs & 5843.25 & 5931.45 & 2637.4 \\
Feeding costs & 3377.58 & 2897.6 & 1153.3 \\
$\quad$ Labor & 1153.3 & 1153.3 & 66.35 \\
Vet. cost & 66.35 & 66.35 & 9859.55 \\
Total variable cost: & 10440.48 & 10048.70 & 3055.43 \\
Total gross margin & 2263.8 & 2724.18 & 436.49 \\
Economical Efficiency & 323.4 & 389.17 & 1.31 \\
Benefit/Cost ratio & 1.22 & 1.27 & 27.4 \\
Break-even price (LE) & 29.5 & 28.3 & 40.2 \\
Break-even yield (kg) & 42.6 & 41.0 & \\
\hline 1, Diets were: G1, free Azzawi date (Control), G2, 50\% Azzawi date (D50), and G3, 100\% Azzawi date (D100). \\
*calculated based on the prevailing price in 2012. Date LE 1000, and hay LE 1600/ton, CFM 2000/ ton, corn grains LE \\
2300 / ton. The price of one kg live body weight on selling was 35 LE. &
\end{tabular}

\section{CONCLUSION}

Under current semi-intensive production system, the inclusion of Azzawi of date in sheep feeding diets did not affect negatively digestibility, growth performance or carcass traits. Also, The cost of carcass gain decreased with increasing level of Azzawi date.

\section{REFERENCES}


Al-Dabeeb, S.N, 2005. Effect of feeding low quality date palm on growth performance and apparent digestion coefficients in fattening Najdi sheep. Small Ruminant Reseacher, 57:3742 .

Al-Dabeeb, S.N., M.A. Mehaia and M. H. Khalil, 2009. Effect of feeding discarded dates on milk yield and composition of Aradi goats. Small Ruminant Research, 81(2-3):167-170 .

Almitairy, A.N., A.M. Alowaimer, El-Waziry and G.M. Suliman, 2011. Effects of Feeding Discarded Dates on Growth Performance and Meat Quality Traits of Najdi Lambs. Journal of Animal and Veterinary Advances, 10 (17): 2221-2224.

AOAC, Association of Official Analytical Chemists, 2000. Official Methods of Analysis, 16th ed. AOAC, Arlington, VA, USA.

Belal, S. Obeidat, Abdullah Y. Abdullah and Fatima A. Al-Lataifeh, 2008. The effect of partial replacement of barley grains by Prosopis juliflora pods on growth performance, nutrient intake, digestibility, and carcass characteristics of Awassi lambs fed finishing diets. Animal Feed Science Technology, 146:42-54.

Duncan, D.B., 1955. Multiple range and multiple F tests. Biometrics, 11:1-42.

El-Asheeri., A.M., 2008. Profitability of Baladi calf feedlots under different fattening systems. Egyptian Journal of Animal production, 45:5767

El-Hag, G.A., Y.M. Al-Yousef and F.N. AlMulhim, 1993. A study of different proportions of dates in the ration of sheep. In: Proceed-ings on the III Symposium on the Date Palm in Saudi Arabia. King Faisal University, Al-Hassa, KSA, pp. 343-350.

El-Gasim, E.A., Y.M. Al- Yousef and A. G. M. Humeida, 1998. Hormonal activity of date pits and flesh used as animal feed for meat animals. Proceedings of the 2nd Symposium on Date Palm, (DP'86), King Faisal University, Saudi Arabia, pp: 425-431.

El-Gasim, E.A., G.A. El-Hag, A.H. Khattab, A.I. Mustafa and I.E. Al-Shaib, 1986. Chemical and nutritional evaluation of the by-products of date processing industry. Proceeding of the Second Symposium on Date Palm in Saudi Arabia, 11: 181-194.

Hmeidan, M.C., G.A.El-Hag, M. Al-Dosary, Y.M. Al-Yousef and I.Al-Turki, 1993. Use of dates as an alternative energy source in sheep fattening rations. 1. A digestibility trial. In: Proceedings of the III Symposium on the Date Palm in Saudi Arabia. King Faisal University, Al-Hassa, KSA, pp. 359-366.

Harb, M., 1994. The use of cereal grains in intensively fattening Awassi lambs to high live weights. Dirassat, 21, 67-76.

Khattab, I., A. Abd-Elwahed and K. Kewan, 2012. The use of In Vitro gas production technique to predict the nutritive value of Azzawi date palm as a replacer for yellow corn grain in ruminant diets under Siwa Oasis conditions. Egyptian Journal of Nutrition And Feeds 15 (1) (Special Issue) 169:178.

Koch, R.M., L.A. Siger, D. Chambers and K.E. Gregory, 1963. Efficiency of feed use in beef cattle. Journal of Animal Science 22: 486.

National Research Council (NRC), 1985. Nutrient Requirements of sheep. $6^{\text {th }}$. ed. National Academy of Sciences, Press Washington D.C., USA

Safari, J. G., D. E. Mushi, L. A. Mtenga, G. C. Kifaro and L. O. Eik, 2011 Growth, carcass yield and meat quality attributes of Red Maasai sheep fed wheat straw-based diets. Tropical Animal Health and Production 43: 89-97 .

SAS, 2004. Statistical Analysis System. SAS statistics. Guide release, version 8.00 TS level OOMO, SAS Institute Inc., Cary, NC,

Sen, U., E .Sirin, Z. Ulutas and M. Kuran, 2011 Fattening performance, slaughter, carcass and meat quality traits of Karayaka lambs. Tropical Animal Health and Production, 43: 409-416.

Suliman, G. M and S. A. Babiker, 2007 Effect of diet-protein sources for lamb fattening. Research Journal of Agricultural and Biological Science, 3(5):403-408. 
أداء النمو وصفات الأبيحة والكفاءة الأقتصادية فى حملان الإغنام البرقى المغذاة على البلح العزاوى منى محمدى ابراهيم ، إبراهيم محمد خطاب ، محمد فرج شحاتة ، عادل محمد عبد الواحد ، خالد زين العابدين كيوان شعبة الإتتاج الحيوانس والدواجن، مركز بحوث الصحراء، 1 ش متحف المطرية، المطرية، القاهرة، مصر

أجريت هذة الدر اسة بهدف دراسة تأثير إستخدام مستويات مختلفة من البلح العز اوى فى علائق الحملان البرقى على أداء النمو وكفاءة تحويل

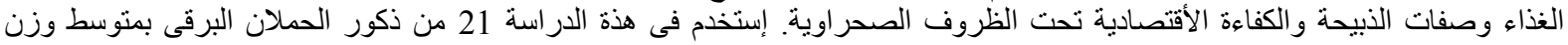

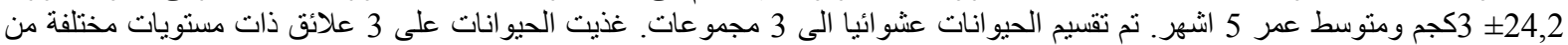

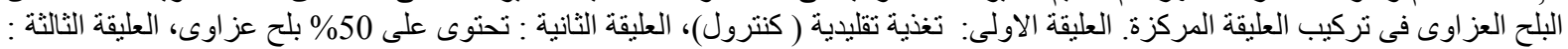

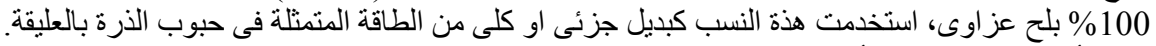

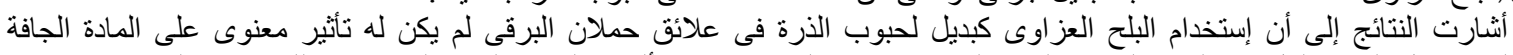

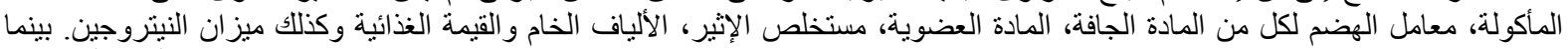

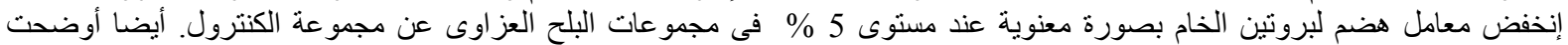

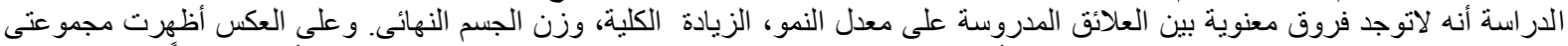

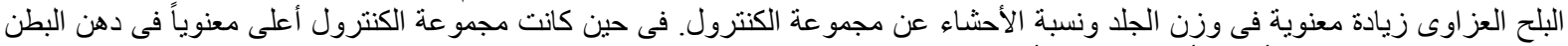

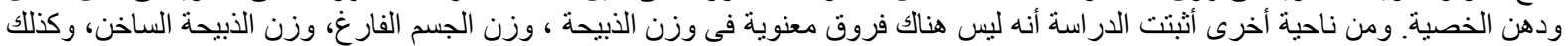
نسب التصافى بين المجمو عات الخدية الثناثلاث.

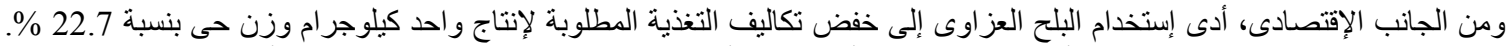

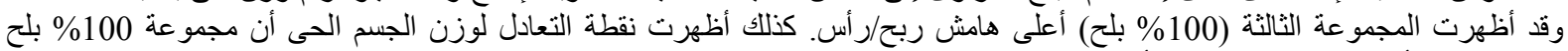

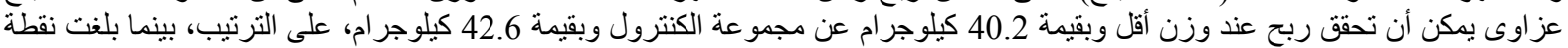

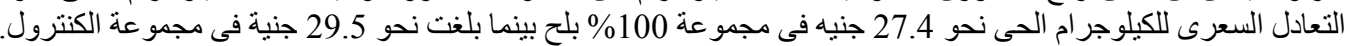

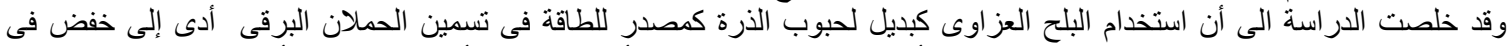

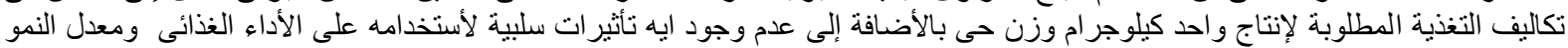
وكفاءة تحويل الغذاء وبعض صلغ صلفات الذبيحة . 